\title{
Jesus Christ in the Postmodern University
}

\author{
Fernando M. Lopena Jr \\ University of the Assumption, Pampanga, Philippines
}

\begin{abstract}
Teaching the Catholic religion in the University setting is very challenging especially now that we are living in the postmodern world. In the context of the postmodern world, there can arise two questions: First; "Having in mind a challenge of the postmodern world, that is incredulity to grand narratives, is it better to remove the Catholic religion in the curriculum since it is a form of a grand narrative?" And second; "Having in mind a phenomenon that the postmodern world brings which is hyperreality, what happens to the teacher and to the student of the Catholic religion in the classroom?” This paper will try to make sense of those questions by exploring first our postmodern world through the lens of two great postmodern philosophers namely Jean-Francois Lyotard and Jean Baudrillard.
\end{abstract}

Keywords: grand narrative, language game, hyperreality, transfiguration, Jesus Christ

\section{Introduction}

I have been a teacher of the Catholic religion for seven years now (one year in the High School level and six years and counting in the College level). In those years, I have often wondered if I am making a difference in the lives of my students. Knowing some of my weaknesses as a teacher especially in the earlier years of my teaching and knowing that most of the students treat the Catholic religion subject as a minor subject even if we belong to a Catholic University, I felt I was not really making a difference in helping them to become more human. I am also aware that our Catholic religion class is only one of the voices that the students are hearing now in a society with lots of spectacles that seduce them to listen and indulge. I think one of the big reasons for the loss of interest of many students to the Catholic religion subject is the shift in the understanding of the essence of our humanity which can be seen from trying "to be more" into trying "to have more" which is a great consequence of the culture of spectacles we have in our society that promotes a consumerist mentality. Most people including the young are more concerned now not with what they can be but rather with what they can have although what one has will have an effect to what one is. In the article of Dante Luis Leoncini titled "From Friend to Legend", he stated there that the meaning of terms like beautiful and good have been perverted because of the prevalence of materialism in our culture. That is why when someone says that one has or lives a good or beautiful life, what is actually meant is that one lives a life of material convenience. In that example, we can see that wealth which is a quantifier was used to qualify or judge a person's life as good or beautiful. ${ }^{1}$ Actually trying to have more or striving for material convenience is not wrong in itself if it will just be a means towards a good end like providing for the security of one's family and contributing for the common good. It only becomes wrong when it is already an end and thus, destroying one's humanity in the process. That is why

Fernando M. Lopena Jr, MERVE, MPR, Associate Professor, University of the Assumption.

Correspondence concerning this article should be addressed to the author. E-mail: jrlopena26@gmail.com.

1 Dante Luis P. Leoncini, "From Friend to Legend," in Tao Po? Readings in Philosophy of Person, ed. Leni DLR Garcia (Quezon City: C \& E Publishing, Inc., 2013), 432. 
religion is very important to remind us of what matters most in our human life which is unfortunately in my observation is not becoming relevant to many students in the classroom setting because of the impact of other forces in their lives like materialism. This is a great challenge for teachers of Catholic religion like me. It is now worth knowing "how is the state of the Catholic religion in the Philippines?”.

In the journal Philippine Sociological Review, it indicated there that the study of the Social Weather Stations has documented a declining trend in church attendance among Filipino adults from 66\% in 1991 to 43\% in 2013. Among Catholics, the decline is from 64\% in 1991 to $37 \%$ in 2013. Although this study indicates that there is a decline in religiosity in general and religiosity in Catholicism understood in terms of church attendance, it is not an adequate indicator of the state of religiosity in the Philippines. It is because religiosity can also be understood as personal belief in God, in which Filipinos rate very highly. The same journal indicated that $91.9 \%$ of Filipinos believe in a personal God, 93.5\% profess always having believed in God, and 83.6\% say that "I know God really exists and I have no doubts about it." Also in the Philippines, there is the emergence of religious innovations that reinvigorate religious life not just in Catholicism but also other traditions. Charismatic renewal movements in the Catholic and Evangelical churches have become noteworthy as religious spaces for finding personal meaning, with consequences on behavioral and upward mobility. These instances and many others suggest that there are other indicators demonstrating vibrant religiosity in the midst of seemingly declining church attendance. Despite of the good news of the state of religiosity in the Philippines, we also need to be aware of the observance of some people that many Catholic youth are drawn to the communal and highly experiential modes of spirituality available in other Christian churches. So the issue here has to do more with institutional Catholicism than with the overall state of religious life in the Philippines. ${ }^{2}$ That is another great challenge for teachers of Catholic religion, that is, how to make the classes more communal and more experiential to be more relevant to the lives of the students in their search for personal meaning in their lives.

Those are some of the challenges in teaching the Catholic religion in the University. Those challenges are even made more complex with the challenges that the postmodern world brings to us like incredulity to grand narratives emphasized by Lyotard and the phenomenon of hyperreality emphasized by Baudrillard. We now try to make sense of the postmodern world through the lens of two great postmodern philosophers namely Jean-Francois Lyotard and Jean Baudrillard.

\section{The Postmodern World Through the Lens of Lyotard}

Jean-Francois Lyotard (1925-1998) is a French philosopher who gained international fame in 1974 for his great work titled The Postmodern Condition: A Report on Knowledge. In this work, Lyotard examines the status of knowledge in the postmodern world and its implications on how we live our life like the games played in research and teaching in the University setting. The main problem that he tackled in this work is the legitimation of knowledge, particularly scientific and narrative knowledge, using the method of "language games” that he got from an Austrian philosopher named Ludwig Wittgenstein.

For Lyotard in the postmodern world, there is a great tendency to equate knowledge with just scientific knowledge making narrative knowledge not knowledge at all. And with the technological revolution that we are experiencing right now, there is what we can call "the computerization of society" which implies

${ }^{2}$ Manuel Victor J. Sapitula and Jayeel S. Cornelio, "A Religious Society? Advancing the Sociology of Religion in the Philippines,” in Sociology of Religion. Spec. issue of Philippine Sociological Review. 62 (2014): 1-3. 
commodification of knowledge. As Lyotard stated, "Knowledge is and will be produced in order to be sold, it is and will be consumed in order to be valorized in a new production; in both cases, the goal is exchange.” ${ }^{3}$ In this context, he also hypothesized that it is conceivable that the nation states will one day fight for control of information, just as they battled in the past for control over territory. ${ }^{4}$ This development in the conception of knowledge undoubtedly influenced the consumerist mentality of the people especially the students in their attitude towards subjects that do not belong to the category of scientific knowledge but rather to the category of narrative knowledge like the subject "Catholic religion".

Lyotard gave two objections against the unquestioning acceptance of an instrumental conception of knowledge in the postmodern world. First, knowledge is not the same as science; and second, science, far from successfully obscuring the problem of its legitimacy, cannot avoid raising it with all of its implications, which are no less sociopolitical than epistemological. In relation to the first objection, knowledge in general cannot be reduced to science which is composed of denotative statements that can be declared true or false. Knowledge is not only a set of denotative statements. It also includes the notions of "know-how", "knowing how to live" etc. Knowledge then is a question of competence that goes beyond the simple determination and application of the criterion of truth, extending to the determination and application of criteria of efficiency (technical qualification), of justice and/or happiness (ethical wisdom), of the beauty of a sound or color (auditory and visual sensibility), etc. ${ }^{5}$ This conception of knowledge, I believe, should make us realize that scientific and narrative knowledge are equally important for us to realize our true humanity especially in the school setting. In relation to the second objection, the problem of legitimation is the central problem that Lyotard tackled in his great work The Postmodern Condition: A Report on Knowledge not only in relation to scientific knowledge, but also to narrative knowledge. In relation to the legitimation of scientific knowledge, we cannot anymore resort to realistic epistemology which conceives of representation as the exact reproduction, for subjectivity, of an objectivity that lies outside it, which is what has been called "crisis of representation" because of so many factors which began in art but has immediate philosophical and ideological implications. Lyotard stated, "The question of the legitimacy of science has been indissociably linked to that of the legitimation of the legislator since the time of Plato." That is why, "in the computer age, the question of knowledge is now more than ever a question of government." In this context, we can say that what we call knowledge is the result of the power of the authorities in declaring those as knowledge in the form of the approval of the recognized experts in the scientific fields at hand. That is why we need critical thinkers who will challenge the accepted forms of knowledge coming from the authorities which are oftentimes totalizing that implies a sense of terror in the sense of trying to fit everything to their mentality where in fact, I believe, everyone has the right and the ability to arrive at "real knowledge" coming from the specific and unique context where one is coming from because everyone belongs to different language games. That is why Lyotard used the theory of "Language Games" of Wittgenstein to arrive at the kind of legitimation that he thinks is the right one in legitimating knowledge whether scientific or narrative knowledge in the postmodern world. The meaning of language games can be put as the comprehensibility of the languages that we utter are dependent of the forms of life where they are used, that is the specific game at play at that moment which implicitly contains the rules. Now, the question is how

\footnotetext{
3 Jean-Francois Lyotard, The Postmodern Condition: A Report on Knowledge, trans. Geoff Bennington and Brian Massumi (Minneapolis: University of Minnesota Press, 1984), 4.

${ }^{4}$ Ibid., 5.

${ }^{5}$ Ibid., 18.

${ }^{6}$ Ibid., 8-9.
} 
did Lyotard legitimate knowledge, scientific and narrative knowledge.

The legitimation of narrative knowledge in the postmodern society does not depend on a single grand narrative outside itself but by simply doing what it does. Each story, while it is being told, is its own proof. ${ }^{7}$ To better illustrate this idea, Lyotard stated, “the narrator's only claim to competence for telling the story is the fact that he has heard it himself. The current narratee gains potential access to the same authority simply by listening. It is claimed that the narrative is a faithful transmission and that it has been told 'forever' ." In other words, the narratives themselves have the authority. In a sense, the people are only that which actualizes the narratives by putting them into play ${ }^{8}$ in the local context where they belong. It is worth noting here that the legitimacy of the narratives is only valid for the people belonging to a particular language game and in turn, people should respect the legitimacy of other narratives belonging to people from another language game which may be incommensurable to one's language game.

In relation to the legitimation of scientific knowledge, Lyotard stated, "It is not inconceivable that the recourse to narrative is inevitable, at least to the extent that the language game of science desires its statements to be true but does not have the resources to legitimate their truth on its own." In other words,

scientific knowledge cannot know and make known that it is the true knowledge without resorting to the other, narrative, kind of knowledge, which from its point of view is no knowledge at all. Without such recourse it would be presupposing its own validity and would be stooping to what it condemns: begging the question, proceeding on prejudice. ${ }^{9}$

That is why scientific knowledge resorted to narratives to legitimate itself which are the speculative narrative and the narrative of emancipation, one is more philosophical and the other is more political. The speculative narrative is delegitimated by Lyotard, because you need to presuppose the Life of the Spirit which cannot be legitimated to unite different language games which are the language game of science and the language game of ethics. The narrative of emancipation is delegitimated also by Lyotard, because the language game of ethics is forced to legitimate the language game of science which belongs to different language games which means that they cannot legitimate one another. If we pursue more this delegitimation, the road will be open to an important current of postmodernity. As Lyotard stated, "Science plays its own game; it is incapable of legitimating the other language games (or be legitimated by other language game). The game of prescription, for example, escapes it. But above all, it is incapable of legitimating itself, as speculation assumed it could.”10 Those two narratives that Lyotard delegitimated are forms of grand narratives or metanarratives. That is why for Lyotard, one of the main characteristics of postmodernity is incredulity to grand narratives which claims to provide universal rational explanations and even norms to all language games. Lyotard claims that knowledge can only be legitimated from one's own linguistic practice and communicational interaction.

Unfortunately, because of the loss of legitimation of scientific knowledge in the postmodern world, the games of research and education in schools resorted to performativity as the criterion to legitimate scientific knowledge. In the field of research, especially with the advent of technology, the goal of the game pertained not to the true, the just, or the beautiful, but to efficiency: A technical "move" is good when it does better and/or expends less energy than another. Researches that aim to improve performance are given more funds than pure research. Because of this, Lyotard stated, "It was more the desire for wealth than the desire for knowledge that

\footnotetext{
7 Jim Powell, Postmodernism for Beginners (New York: Writers and Readers Publishing, Inc., 1998), 33.

8 Lyotard, 20, 23.

9 Ibid., 28-29.

10 Ibid., 40.
} 
initially forced upon technology the imperative of performance improvement and product realization." ${ }^{, 11}$ In the field of education, postmodern students will be more concerned with the question "What use is it?" rather than "Is it true?". ${ }^{12}$ That is why subjects like the Catholic religion appeal less to students nowadays, because of the consumerist mentality that the criterion of performativity brings to us. It is because subjects like the Catholic religion offer is not something that can be quantified and it takes time to attain.

Ultimately, for Lyotard, postmodern knowledge is producing not the known, but the unknown. This suggests a model of legitimation that has nothing to be with maximized performance, but it has as its basis difference understood as paralogy ${ }^{13}$, which can be understood as the search for instabilities and not a consensus of a given system. When Lyotard stated that postmodern knowledge is producing the unknown, I think it means that legitimation by paralogy will make us more aware of the unknown that exist in our midst. And in order to attain a just world in the postmodern world, Lyotard gave us two steps. First is the recognition of the heteromorphous nature of language games which implies a renunciation of terror which means trying to impose one's ideology to the rest without respecting their uniqueness. The second step is the principle that any consensus on the rules defining a game and the "moves" playable within it must be local, in other words, agreed on by its present players and subject to eventual cancellation. ${ }^{14}$

This state of postmodern world through the lens of Lyotard is something that Catholic educators should know, in order to become more relevant in teaching the Catholic religion in the classroom. With this state in mind, the challenge in teaching the Catholic religion really becomes more complex, but it's very important to know, so that one can reflect more about the practices that one is doing which may be wrong. One of the main charges of this account of the postmodern world to the teaching of Catholic religion in the University is incredulity to grand narratives, because the Catholic religion is a form of a grand narrative which means it may be a hindrance in respecting the language games of the students. We now turn to another great postmodern philosopher named Jean Baudrillard.

\section{The Postmodern World Through the Lens of Baudrillard}

Jean Baudrillard (1929-2007) is a French philosopher, sociologist, cultural and media critic. One of his great works is titled Simulacra and Simulation where he deeply examined the phenomenon of hyperreality in the postmodern world. There is a tendency to look at Lyotard's account of the postmodern world presented in this paper in a positive way but Baudrillard's account of the postmodern world is in a negative mood.

Baudrillard began the book by quoting Ecclesiastes which states, "The simulacrum is never what hides the truth—it is truth that hides the fact that there is none. The simulacrum is true.” The quote already gives us an essence of the nature of simulacrum. The truth of simulacrum is that there is no truth, except the play of signs as a result of the loss of reference in the postmodern world. As a result there is a loss of meaning in people's lives which is a great challenge that we must face. To understand this phenomenon of simulacrum, Baudrillard stated, "Simulation is no longer that of a territory, a referential being, or a substance. It is the generation by models of a real without origin or reality: a hyperreal. ${ }^{, 15}$ In other words, simulation creating simulacra brings us to another dimension, what Baudrillard called hyperreal, which is neither true nor false, neither real nor

11 Ibid., 44-45.

12 Ibid., 51.

13 Ibid., 60.

14 Ibid., 66.

15 Jean Baudrillard, Simulacra and Simulation, trans. Sheila Faria Glaser (USA: The University of Michigan Press, 1994$), 1$. 
imaginary, but rather it is just operational. In the hyperreal world, there is a great tendency for us to be fascinated with the play of signs that are happening but at the same time, we are being dehumanized. In spite of this, there is also a great tendency in us to try to retain the fascination because we are more afraid to know, deep within, that beneath those signs, there is emptiness because of the loss of reference in the postmodern world. We are caught up in the play of signs that can be something irreversible that makes it a big challenge to reclaim the real, if that is still possible.

To better understand the dangers posed by simulation in our lives, Baudrillard compared the dangers presented by a real holdup and a simulated holdup. For him, a simulated holdup is infinitely more dangerous than a real holdup because the latter does nothing but disturbs the order of things, the right to property whereas the former attacks the reality principle. ${ }^{16}$ What makes the hyperreal produced by simulation more dangerous is to attack hyperreality by trying to restore the reality principle, what can actually happen is just contributing to the play of signs that happens in hyperreality. Now the question is how will this phenomenon of hyperreality affect our culture, the way we live our lives.

In the modern world, we can say that culture was of liberating violence (rationality). In the postmodern world, Baudrillard stated,

A whole other violence appears today, which we no longer know how to analyze, because it escapes the traditional schema of explosive violence: implosive violence that no longer results from the extension of a system, but from its saturation and its retraction. ${ }^{17}$

To better understand the meaning of implosive violence he is talking about, we need to clarify the meaning of implosion which he also gave. He also stated,

Implosion is the absorption of one pole into another, the short-circuiting between poles of every differential system of meaning, the erasure of distinct terms and oppositions, including that of the medium and of the real—thus the impossibility of any mediation, of any dialectical intervention between the two or from one to the other. ${ }^{18}$

In this context, we can say that in a simulated society, because of the destruction of disconnection between the subject and the object, in watching TV, what happens is not really you watching TV but rather you being watched, and in purchasing something to the market, what happens is you being purchased. Because of this phenomenon of hyperreality which seduces people in the play of signs and also because of the phenomenon of implosion, according to Demeterio, the postmodern person has become an insatiable consumer in the fact that he/she has transformed from a consumer of goods into a consumer of signs. It is because in this time, individuals achieve their identities through the prestige symbols/signs that they consume. ${ }^{19}$

Hyperreality is indeed a very big challenge that we need to face in our postmodern world. Because of this, a new form of nihilism is in our midst which Baudrillard described in this way: "Today's nihilism is one of transparency, and it is in some sense more radical, more crucial than in its prior and historical forms, because this transparency, this irresolution is indissolubly that of the system, and that of all the theory that still pretends to analyze it.” In the past, nihilism took the form of metaphysical radicality born of the death of God but today,

\footnotetext{
16 Ibid., 20.

17 Ibid., $71-72$

18 Ibid., 82-83.

19 F. P. A. Demeterio, “Understanding the Postmodern Culture and Philosophy," in Exploring the Philosophical Terrain, ed. Leni DLR Garcia (Quezon City: C\& E Publishing, Inc., 2013), 399.
} 
God is not dead, he has become hyperreal. ${ }^{20}$ That is why there is what we can call simulacrum of divinity. Through the symbols/signs that we have of God, there is a great tendency and I think it is happening, that God will become hyperreal wherein we become lost to the play of signs/symbols/images that we have of God and in the process erasing the real reference of God in our lives. That is why, in a sense, we can say that the signs/symbols/images that we have in our religion become circus because they point to God but they don't communicate God because we are lost in the symbols.

The challenge that the postmodern world brings to us through the lens of Baudrillard indeed became very complex particularly in the context of teaching the Catholic religion in the classroom and it may even give us the feeling that our humanity is doomed because of what is happening which can be something irreversible. The phenomenon of hyperreality emphasized by Baudrillard definitely would make the true Catholic educator in the University think deeply about how to be an effective teacher knowing that the phenomenon of hyperreality affects everywhere and everyone, and obviously that includes the teacher himself/herself. We now turn to the narrative of "The Transfiguration of Jesus" and the five popular images of Jesus in the Philippines to be able to make sense of the two main questions in this paper in the context of the highly challenging uncommon complexity that the postmodern world brings.

\section{“The Transfiguration of Jesus" and the Five Popular Images of Jesus}

First, here is the narrative of "The Transfiguration of Jesus" taken from the Gospel of Luke 9:28-36.

Jesus took Peter, John, and James with him and went up a hill to pray. While he was praying, his face changed its appearance, and his clothes became dazzling white. Suddenly two men were talking to him. They were Moses and Elijah, who appeared in heavenly glory and talked with Jesus about the way in which he would soon fulfill God's purpose by dying in Jerusalem. Peter and his companions were sound asleep, but they woke up and saw Jesus' glory and the two men who were standing with him. As the men were leaving Jesus, Peter said to him, "Master, how good is it that we are here! We will make three tents, one for you, one for Moses, and one for Elijah."

While he was still speaking, a cloud appeared and covered them with its shadow; and the disciples were afraid as the cloud came over them. A voice said from the cloud, "This is my Son, whom I have chosen—listen to him!”

When the voice stopped, there was Jesus all alone. The disciples kept quiet about all this and told no one at that time anything they had seen. ${ }^{21}$

The transfiguration of Jesus which ancient tradition locates in Mount Tabor, is indicated by the verb metemorphothe, transfiguratus est, which supposes a change, not in the person itself, but in the figure in which it normally appears. This means that Jesus didn't abandon his original person to become someone else, but by a change of "figure" which allows his divine persona (Christ) to shine forth—in exemplary fashion—-through his flesh-and-blood embodiedness. ${ }^{22}$ This passage highlights the transcendental nature of Jesus which can be seen in the verse "While he was praying, his face changed its appearance, and his clothes became dazzling white." This transcendental nature of Jesus is not something that we can fix or even approximate. Trying to do so

\footnotetext{
${ }^{20}$ Baudrillard, 159.

${ }^{21}$ Good News Bible with Deuterocanonicals: Today’s English Version. Philippines: Philippine Bible Society, 1992.

22 Richard Kearney, “Transfiguring God," in The Blackwell Companion to Postmodern Theology, ed. Graham Ward. (USA: Blackwell Publishing Ltd, 2005), 378.
} 
makes him an idol which is a distortion of the truth that will lead to other distortions.

When the disciples saw Jesus transfigured before their eyes, their immediate reaction is found in the verse "As the men were leaving Jesus," Peter said to him, "Master, how good is it that we are here! We will make three tents, one for you, one for Moses, and one for Elijah,” which shows their idolatrous impulse. This effort of the disciples to fix Jesus as a fetish of presence, imposing their own designs on him, makes it necessary for God to intercede from the cloud and bid them attend to Christ's otherness: "Listen to him!",23 The important lesson that we can learn here is that we should never try to represent something entirely without leaving anything to the imagination. In the first place, that is not possible and if we will try to do it, we are distorting the truth of an event and if our reference is not an event but a person, then we are distorting the nature of a person. On the other hand, I think there is nothing wrong in trying to represent something/someone as long as we are always aware of the nature of that something/someone as both present and absent with more emphasis on the "absent".

In 2 Corinthians 3:18, St. Paul suggested that the scene on Mt. Tabor is a call to each one of us to become transfigured in the light of Christ. Such transfiguring is done unto us by the grace-giving persona of Christ but it is also something we can and we should do to others in turn, indeed in return. That is why we have an ethical choice to transfigure our world according to the Christic figure of love and justice as icon of the end-to-come, or to fix him as an idol of presence-whose only end is in itself. The choice is between Christ as transformation or as fixation. ${ }^{24}$ That is why this persona is very important to understand the person of Jesus. We need to realize what this means although it is beyond words. What we need to realize is that if we understand the person of Jesus without the persona of Christ, we will not know the essence of the Catholic message. When we understand the persona of Christ in the personhood of Jesus, we will realize that everyone has a persona that needs to be respected.

Each person has a persona. Persona is that eschatological aura of "possibility" which outstrips but informs a person's actual presence here and now. It is another word for the otherness of the other. It is beyond consciousness, although I think it is the one that makes consciousness possible. In our encounter with the other, we always configure them. To configure the other as a persona is to grasp him/her as present in absence, as both incarnate flesh and transcendent in time. To accept this paradox is to transfigure the other, allowing this other to appear as his/her unique self. So when we see the persona in and through the other, we respect his/her uniqueness which is always the right thing to do. It is because this divine persona is what both safeguards what is unique in each one of us—-what stitches each in its mother's womb, what knows every hair of our head—and what convenes us in a shared humanity. On the other hand, when we refuse the paradox, opting instead to regard someone as pure presence (thing) or pure absence (nothing), we defigure the other. ${ }^{25}$ I think that is the main challenge of the narrative of "The Transfiguration of Jesus", that is, to transfigure and not to defigure the other. Unfortunately, it seems that it is inherent in the nature of our humanity to fall into idolatry like in trying to treat the persona of Jesus as an object just like what the disciples in the narrative tried to do. This is a struggle that we need to face to fulfill our humanity. This challenge of the narrative, that is, to transfigure the other and in the process, respecting otherness and celebrating difference, is an essence of the message of the Catholic religion. This means that although the Catholic religion is a form of a grand narrative, there is nothing

\footnotetext{
23 Ibid., 380.

24 Ibid., 381.

25 Ibid., 371, 382.
} 
wrong in the essence of its message. It respects little narratives in the form of trying to understand the language games of people and being able to transfigure the other. Although there is nothing wrong in the essence of the Catholic religion, when the subject is already being taught in the classroom, it will not be easy to transfigure and not to defigure the message especially having in mind the phenomenon of hyperreality that the postmodern world brings. It will undoubtedly be a great challenge. To show how hard it is to teach the Catholic religion in the classroom without defiguring, five popular images of Jesus in the Philippines will be analyzed using the framework of the narrative of "The Transfiguration of Jesus".

First is the image of Sto Niño. This reflects the Filipinos being "family-oriented". The anak-magulang (child-parent) relationship is very important. The terms Ama, Ina, and Anak (father, mother, and child) are significant to us because we value so much our attachment to our family. The Catholic message is transfigured in this image when through this image, it fosters our traditional love for children and also, when we treat each member of the family with genuine love when everyone's uniqueness is respected. But then with this image, the Catholic message is also defigured when the family becomes the only important thing in this world for the person up to the point of protecting the family even at the cost of the common good. For example, the cultural practice of nepotism which is favoritism shown to relatives in conferring offices and with it, the culture of political dynasty. ${ }^{26}$

Second is the image of Host. This reflects the Filipinos being meal-oriented. The Catholic message is transfigured here when through this image, we become gracious hosts and grateful guests in every gathering. ${ }^{27}$ However, the Catholic message is defigured in this image when our focus is turned to the food or things that we can give to the other so that the other will be pleased to us. In this way, the other becomes an object for us to feel good which is a defiguration of the Catholic message. The Catholic message is also defigured here when we become lovers of food up to the point of not taking care of our bodies anymore.

Third is the image of Suffering Servant. This reflects the Filipinos being kundiman-oriented. The kundiman is a Filipino song about love, especially wounded love. Filipinos are naturally attracted to heroes sacrificing everything for love. The Catholic message is transfigured here when through this image, we still try to understand other people even when they hurt us. Also, through the images of Hesus Nazareno, the Crucified Christ, and the Santo Entierro, the Catholic message is transfigured when we become open to the mystery of life like being able to experience God through suffering and being able to feel as one with the suffering people like the hungry, the thirsty, the naked, the lonely, the stranger, and the prisoner. ${ }^{28}$ On the other hand, the Catholic message is defigured here when we see suffering as an important way for us to go to heaven. Also unconsciously, through this image, we may project God the Father as a sadist God, one who likes to see people suffer, and project God the Son as a masochist, one who likes to suffer, which is definitely a defiguration of the Catholic message wherein we put our human understanding to the Catholic narrative.

Fourth is the image of Christ the King. This reflects the Filipino attitude of optimism. The Catholic message is transfigured here when we see ourselves and others, no matter what we have gone through and no matter how seemingly lowly other people are, always with hope. ${ }^{29}$ The Catholic message is defigured here when optimism is overemphasized in the sense that we do not anymore listen to our or other people's problems.

\footnotetext{
${ }^{26}$ Lode Wostyn, ed., Believing Unto Discipleship: Jesus of Nazareth (Quezon City: Claretian Publications, 2003), 6, 10.

27 Ibid., 7.

${ }^{28}$ Ibid., 7-8.

${ }^{29}$ Ibid., 8.
} 
In other words, we do not face anymore our difficulties but rather, we only try to have hope always. Also, the Catholic message is defigured here when we put so much emphasis on Divine providence wherein we believe the future will be alright no matter what we are going through now because of God, even if we will not do much on our part.

Lastly is the image of Miracle Worker. This reflects the Filipinos being spirit-oriented. We have a deep-seated belief in the supernatural and in all kinds of spirits dwelling in individual persons, places, and things. The Catholic message is transfigured here when we become very sensitive to the "Otherness" of the other by recognizing the spirit in the other. However, the Catholic message is defigured here when we see Jesus as a purely divine person, thereby denying his humanity. Also, the Catholic message is defigured here when we put our human understanding to Jesus, unconsciously, as a magician who will grant what we ask for in prayer as long as we believe. ${ }^{30}$

With this sample analysis of the part of the Catholic religion, I think it is now clear that it is not easy to transfigure the Catholic message, because even if we teach only the good things of the Catholic message, there are unconscious elements that are stated in this sample analysis that will have great effect on how students live their life. Again the challenge of teaching the Catholic religion in the classroom even becomes more complex with the phenomenon that the postmodern world brings which is hyperreality. Aside from the negative unconscious elements that the images of Jesus bring to the students, there is a great tendency that students will get loss in the play of images that were given. We have to be aware that those images were already filtered in our culture because the Catholic religion came from a foreign country with a very long and complex history. That is why we can say that the image of Jesus that is being taught in the classroom is the image of the real reference, who is none other than Jesus Christ. And this process of having the image of Jesus Christ will continue in the minds of the students and also in the mind of the teacher. In the process, there will be the loss of reference leading us to have hyperreality of Jesus Christ that can lead to the loss of right meaning in one's life.

With the narrative of "The Transfiguration of Jesus" and the analysis of five popular images of Jesus in the Philippines from the framework of that narrative already given, we now try to give a deeper answer to the two main questions of this paper.

\section{Jesus Christ and the Postmodern World in the School Setting}

The first main question that this paper is trying to answer which was already partially answered is, "Having in mind a challenge of the postmodern world, that is incredulity to grand narratives, is it better to remove the Catholic religion in the curriculum since it is a form of a grand narrative?” As I've already stated, the answer is "No". It is because even if the Catholic religion is a form of a grand narrative, its essence is still good-in-itself using the interpretation that was already given in the narrative of "The Transfiguration of Jesus", that is, trying to transfigure the other which means respecting the differences that exist and being aware of the persona that each one possesses that cannot be possessed in return. In other words, respecting the unique language game where each one belongs or recognizing the little narratives that each one possesses. "This is our deepest need in our increasingly polycentric world, as David Tracy once said, that is, the drive to face otherness and difference. ${ }^{31}$ Although I think the Catholic religion should still be in the curriculum because of its good

\footnotetext{
30 Ibid., 8, 11.

31 Anselm Min, The Solidarity of Others in a Divided World: A Postmodern Theology after Postmodernism (New York: T \& T Clark International, 2004), 173.
} 
essence even if it is a form of a grand narrative, we have to be aware of the dangers that it poses because it is still a grand narrative/metanarrative. It is because again for Lyotard

in the possession of a metanarrative, any one at all, everything is accounted for in a supreme exercise of the comprehension of reality, a tour de force of imagination and a textbook exercise of power in which the Other is only perceived in and through the metanarrative. The power of the narrative renders powerless that which is accounted for. The voice of the Other is unheard, the presence of the Other, as Other, unnoticed. So for Lyotard, the abandonment of metanarrative means the encounter with the Other. ${ }^{32}$

We have to be reminded that the Catholic religion is very rich and very complex in contents with a very long history. That is why even if I think that its essence is good in respecting the otherness of the other, it also possesses grand narratives that doesn't recognize the otherness of the other like the Catholic Church's stand on some burning social issues like divorce, artificial contraception, etc. It is because with so many Catholics around the world, the Catholic religion has become an institution and there is a great tendency to lose her charism, the Spirit that brought her into existence, which is happening at times when people in Catholic organizations become focus on the bureaucracy of the Church and failing to look at the unique situation of each one of us.

From a certain perspective, we cannot really let go in having a grand narrative/metanarrative because the proposal of Lyotard to respect the language games of each one or be tolerant to the incommensurability of language games or recognizing the little narratives of each one can be interpreted as a form of a grand narrative. That is why I think that the grand narrative that Lyotard was against is the narrative that implies a sense of terror in the sense of trying to fit everyone or everything to a certain ideology with the use of force whether physical force or non-physical force. One of the grand narratives that Lyotard was against is the dominance of scientific knowledge in the postmodern world. Knowledge has been equated with scientific knowledge which brought negative impact to our culture especially in the university culture where subjects that are more narrative knowledge are not given lots of attention like the Catholic religion subject even if one belongs to a Catholic University. That is why Lyotard claimed, “Lamenting the 'loss of meaning' in postmodernity boils down to mourning the fact that knowledge is no longer principally narrative.”33 As already stated in this paper, scientific knowledge needs narrative knowledge to legitimate itself. Narrative knowledge indeed is very important like the subject Catholic religion, most importantly, because narrative knowledge gives meaning to our lives. They help us to fulfill our humanity, because I believe that the essence of our human lives is ultimately "narratives".

In our quest for meaning in our lives, a narrative given by Vaclav Havel can help us which can be interpreted also as a grand narrative. That is why it is just a suggestion if it can just help us. Nonetheless, here it goes,

Start with the awareness of our being anchored in the Earth and the universe, the awareness that we are not here alone nor for ourselves alone, but that we are an integral part of higher, mysterious entities. This forgotten awareness to some people is encoded in all religions. All cultures anticipate it in various forms. It is one of the things that form the basis of man's understanding of himself, of his place in the world, and ultimately of the world as such. This awareness endows us with the capacity for self-transcendence. Transcendence understood as a hand reached out to those close to us, to foreigners, to the human community, to all living creatures, to nature, to the universe; transcendence as a deeply and

\footnotetext{
32 Paul Lakeland, Postmodernity: Christian Identity in a Fragmented Age (Minneapolis: Fortress Press, 1997), 32.

33 Lyotard, 26.
} 
joyously experienced need to be in harmony even with what we ourselves are not, what we do not understand, what seems distant from us in time and space, but with which we are nevertheless mysteriously linked because, together with us, all this constitutes a single world. So transcendence is the only real alternative to the extinction of the "Other" ${ }^{34}$

Now the second main question that this paper is trying to answer which was also already partially answered is, "Having in mind a phenomenon that the postmodern world brings which is hyperreality, what happens to the teacher and to the student of the Catholic religion in the classroom?” To answer this question, let us first quote Baudrillard about the successive phases of the image for him: "first, it is the reflection of a profound reality; second, it masks and denatures a profound reality; third, it masks the absence of a profound reality; and lastly, it has no relation to any reality whatsoever; it is its own pure simulacrum." ${ }^{35}$ In the first phase, the image is still directly connected to the reference. It is still a right image. In the second phase, the image is already defigured just like the analysis of the five popular images of Jesus in this paper wherein although there are positive influences, there are also negative and at times unconscious influences. In the third phase, the real reference is already gone. We are already lost in the play of signs/symbols that we have of the image, but I think there is still a certain degree of chance to reclaim the real reference. On the last phase, the real reference is not only gone. It has become something else, a simulacrum, a hyperreality. In this phase, there may be no chance of reclaiming the real reference or if there is still chance, there will be very little chance. In teaching the Catholic religion in the classroom, it is worth reflecting especially from the part of the teacher, what phase is he/she in the process of representing the profound reality of the Catholic religion in the classroom whether through words, actions, or through one's life? This is indeed a great challenge because if the teacher does not have a direct relationship to the real reference, in this case "Jesus Christ", he/she will not really be effective, because it is simply, we cannot give what we don't have. Unfortunately, I think that most of us are living in a hyperreal world where the reference is already lost. We are caught up in the play of signs and as a result, a loss of meaning in our lives. We have what can call now a hyperreal consciousness having a hyperreal God, a hyperreal culture, that is, an implosive culture where we become what we consume in the play of signs. Also taking into consideration the fact that students of Catholic religion in the University are only in the school for a certain period of time and when they are in the school, there is hardship connecting to their language games and hardship connecting to the real reference of the subject which is the most important not only from the part of the students, but also from the part of the teacher. The situation seems irreversible and hopeless. But then one of the lessons of the narratives of the Catholic religion is that "nothing is impossible with God," "no one is hopeless," "there is no such thing as a hopeless irreversible situation." Although it would be really hard, I believe we can do something to make a difference. The most important thing that teachers should do first is to reclaim the real reference of the Catholic religion in one's life, that is, the first-hand experience of God in one's life through the person of Jesus Christ. To do that we need to use our creative thinking more to be able to see how God works in our lives in creative ways. Secondly of course, we need to have a mastery of subject matter, that is, being able to know the essence of the lessons being delivered to students and not get lost in the circus of signs and words in the teaching process but be able to connect to the language of students by creating a communal and experiential atmosphere in the classroom and journey together with them in one's search for authenticity in life. In this part, we need to use more our critical thinking ability in making sense of the essence

\footnotetext{
${ }^{34}$ Vaclav Havel, "The Search for Meaning in a Global Civilization,” in The Truth about the Truth: De-confusing and Re-constructing the Postmodern World, ed. Walter Truett Anderson (New York: G.P. Putnam’s Sons, 1995), 237-238.

${ }^{35}$ Baudrilard, 6.
} 
of the subject. Thirdly, and also very important is developing one's character as a teacher. People learn best through example. That is why we have to develop good habits by developing our character because true or real learning happens, I think, outside the classroom. Aside from developing creative and critical thinking, maybe the most important is being able to develop caring thinking which is very essential in a Catholic religion subject. Caring thinking is about asking oneself honestly, "where is my thinking coming from?" Is it coming from a world of love or from a world of indifference or hate?

In a hyperreal consciousness where there is the loss of reference by being immersed in the play of signs coming from the postmodern world, I think one of the best ways to reclaim our real reference, that is the first-hand experience of God, is through paralogism proposed by Lyotard as the legitimation of postmodern knowledge. This is a search for instability in a system like in the system of hyperreality where we may be in and as a result, producing the unknown. It is because in a hyperreal world, we are immersed with lots of signs without origin and without end. That is why when we do paralogism, we can be aware more of the unknown which I think can help us gradually to break away with the hyperreal world by being closer to the truth.

\section{Conclusion}

The coming of the Catholic religion in the Philippines is seen as a big blessing for many Filipinos. As already stated in this paper, religiosity understood in a wide sense is high in the Philippines. This means that many Filipinos turn to religion like the Catholic religion to find meaning to their lives. Unfortunately, with the phenomenon of hyperreality, there is a great tendency for many Filipinos to get lost in the play of signs/symbols/images that we have in our religion since religion specifically the Catholic religion has a long and complex history. That is why education is very important not just inside the classroom but also outside. That is why Catholic educators whether inside or outside the classroom have a big challenge to face, that is, reclaim first the real reference of the Catholic religion in their lives, that is to have a first-hand experience of God in their lives through the person of Jesus Christ, and guide others to do the same. Once this is done, although we all have weaknesses in our lives, we can be like Jesus Christ in our own unique ways in our lives and as a Catholic educator, be a "Jesus Christ" in the postmodern university.

\section{References}

Baudrillard, J. (1994). Simulacra and simulation. (S. F. Glaser, Trans.). USA: The University of Michigan Press.

Bible Societies. (1992). Good News Bible with deuterocanonicals: Today's English version. Philippines: Philippine Bible Society. Demeterio, F. P. A. (2013). Understanding the postmodern culture and philosophy. In L. D. Garcia (Ed.), Exploring the philosophical terrain (pp. 388-401). Quezon City: C \& E Publishing, Inc.

Havel, V. (1995). The search for meaning in a global civilization. In W. T. Anderson (Ed.), The truth about the truth: De-confusing and re-constructing the postmodern world (pp. 237-238). New York: G.P. Putnam's Sons.

Kearney, R. (2005). Transfiguring God. In G. Ward (Ed.), The blackwell companion to postmodern theology (pp. 371-382). USA: Blackwell Publishing Ltd.

Lakeland, P. (1997). Postmodernity: Christian identity in a fragmented age. Minneapolis: Fortress Press.

Leoncini, D. L. P. (2013). From friend to legend. In Leni DLR Garcia (Ed.), Tao Po? Readings in philosophy of person (pp. 429-447). Quezon City: C \& E Publishing, Inc.

Lyotard, J. F. (1984). The postmodern condition: A report on knowledge. (G. Bennington \& B. Massumi, Trans.). Minneapolis: University of Minnesota Press.

Min, A. (2004). The solidarity of others in a divided world: A postmodern theology after postmodernism. New York: T \& T Clark International.

Powell, J. (1998). Postmodernism for beginners. New York: Writers and Readers Publishing, Inc. 
Sapitula, M. V. J., \& Jayeel, S. C. (2014). A religious society? Advancing the sociology of religion in the Philippines. Sociology of Religion. Spec. issue of Philippine Sociological Review. 62, 1-9.

Wostyn, L. (Ed.). (2003). Believing unto discipleship: Jesus of Nazareth. Quezon City: Claretian Publications. 